
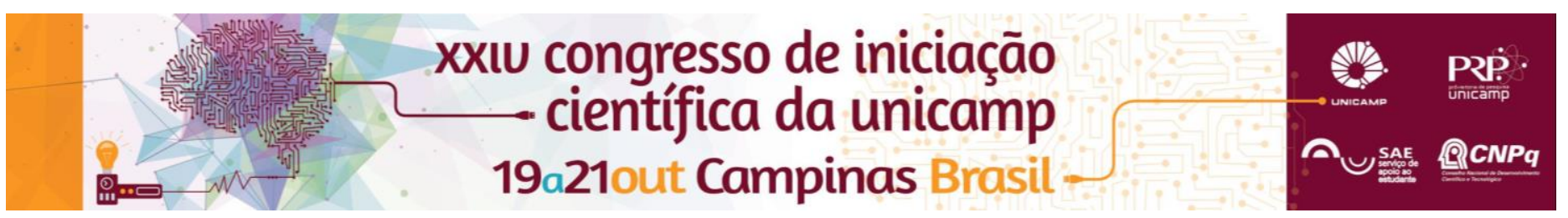

\title{
A Matemática por meio de atividades Interdisciplinares
}

\author{
Victor A.S. da Silva, Jessica P.dos Santos, Isabella B. Godoi.
}

\section{Resumo}

As atividades interdisciplinares desenvolvidas neste projeto, envolvendo a Matemática com outras áreas de ensino, então descritas a seguir : Aritmética: Atividades - Conhecendo o Calendário (História/Muro de Berlin); Descobrir Padrões (jogo ); Números reais/ História do número "pi" ( História Antiga/Egípcios, Babilônios e Sumérios); Teoria dos Códigos/Criptografia (História Moderna/Economia), Leituras de jornais - porcentagem; Geometria plana e espacial: Atividades - Ergonomia / Formas Geométricas (Física); Cristalografia- Prismas e Pirâmides (Química, História/Egito); Alotropia do Carbono, Fulereno, Grafite - Icosaedro Truncado e Poliedros de Platão (Química); Projeções Cartográficas, Latitude, Longitude; Construções de Corpos Redondos - esfera, cone, cilindro (Geografia), Quantidade de pele no ser humano, (medicina), Chapéu da bruxa, planificação do cone (folclore). Geometria analítica: Atividades -obtenção das secções cônicas: Parábola (Física/ cinemática-grandezas vetoriais e escalares;movimento parabólico); Elipse (Geografia/rotação e translação da Terra em torno do Sol, as quatro estações do ano,). Funções: Atividades - Carro Flex (Economia); Escalas de Temperatura (Química, Física e Biologia); Redes sociais - exponencial (Sociologia), "O suspeito"- Logaritmos( Medicina Legal).

Palavras-chave: Matemática, interdisciplinaridade, ensino médio

\section{Introdução}

O projeto possibilitou um trabalho interdisciplinar da Matemática com outras áreas de conhecimento tais como: Química, Física, Geografia, Biologia, Economia, História, Sociologia e Medicina.

As atividades interdisciplinares desenvolvidas tiveram como objetivo apresentar situações-problemas, abrangendo estas áreas e conteúdos matemáticos do EF e Médio.

\section{Resultados e Discussão}

Ao desenvolver as situações-problemas, numa perspectiva de interdisciplinaridade, os alunos puderam explorar sua bagagem de conteúdos formais e culturais na vivência de diferentes experimentos. Foi possível também incentivar a curiosidade, a descoberta do novo e uma maior participação no processo de ensino e aprendizagem.

Os recursos didáticos utilizados, tais como: vídeos, áudios, experimentos, jogos, aplicativos e sites da internet, promoveram a efetiva participação dos alunos e uma aprendizagem mais significativa.

Metodologia - os temas foram apresentados através de vídeos, de reportagens de jornais, slides, simulações de experimentos e de situações-problemas .Nos encontros foram utlizados os recursos e os problemas eram discutidos e resolvidos.

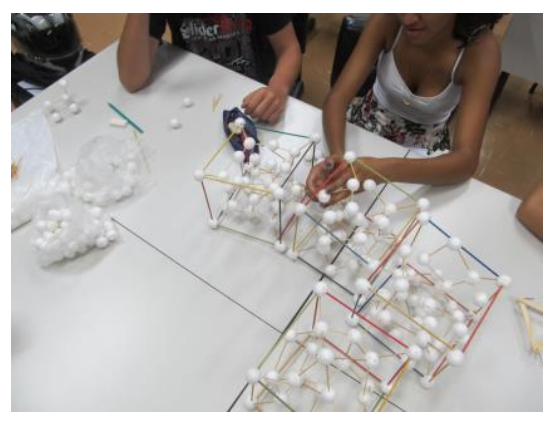

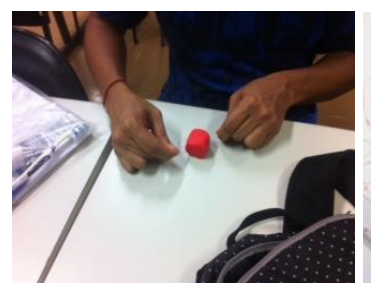

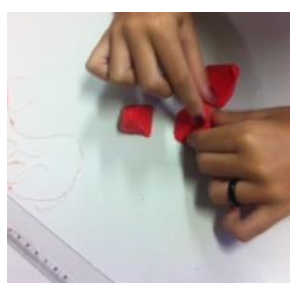

Figura 2. Volume da pirâmide é $1 / 3$ do volume do prisma.

\section{Conclusões}

O projeto foi de grande valia para os estudantes, pois, ao buscarem soluções para os problemas interdiciplinares apresentados verificaram que a Matematica possibilita a busca da solução do problema. Sendo assim trabalhamos com eles conceitos e habilidades matemáticas necessárias

\footnotetext{
Referencias:

www.m3.ime.unicamp.br

Barderas,S. V. Didactica de la Matematica. AS: Editorial La Muralla, 2000

Máximo, A.; Alvarenga, B. Curso de Física,Editora Scipione, 2009.

Dante,L.R.,Matemática, contexto e aplicações, Editora Ática, 2009.
}

Figura 1. Construção do modelo do diamante. 